\title{
The Use of Visual Media in Maharatah al-Kalam Learning
}

\author{
Eka Safitri ${ }^{1 *}$, Ihsan Sa'dudin ${ }^{2}$ \\ ${ }^{1}$ Prodi Ilmu dan Teknologi Pangan Universitas Jenderal Soedirman,Purwokerto, Indonesia \\ ${ }^{2}$ Prodi Bahasa dan Sastra Arab Institut Agama Islam Negeri Syekh Nurjati Cirebon, Indonesia
}

\author{
Article History: \\ Received : March 1 $1^{\text {st }}, 2019$ \\ Revised : April 3 $3^{\text {rd }}, 2019$ \\ Accepted : May $5^{\text {th }}, 2019$ \\ Published : June $1^{\text {st }}, 2019$
}

\section{Keywords: \\ Arabic; Kalam; Learning; Media}

*Correspondence Address:

eka.safitri@unsoed.ac.id

\begin{abstract}
This study presents one of the learning instruments used in teaching Arabic, namely using visual media. This visual media is used as a solution for learning Arabic in the industrial era 4.0 which is easier to receive material with visual media. In practice, this visual media research is not only on media that can be seen, but researchers see several things that must be considered in using visual media including the type of visual media to be used, the principles of its use, how to present it, the mechanism of its creation and selection visual media that can be used for learning maharatul kalam. This visual media is used so that students are more enthusiastic and educators are more able to innovate in learning maharatul kalam. There is also a research method used is a description-analysis with literature review. Among the visual media that can be used to teach maharatulkalam is images, posters, flannel boards, bulletin boards and wall clocks. The results of the study from this study indicate that in using visual-based learning media there are various kinds of rules that aim to realize learning effectiveness. The use of visual media is more interesting for students to continue the learning process because the visual influence has more impact on the ease of understanding the material. There are principles that must be considered when using visual media in learning that is prioritizing simplicity, clear and easy to read.
\end{abstract}

\section{Introduction}

Language learning is a learning that requires creativity from a teacher. In its implementation requires learning innovations that can attract students' attention. With the help of media, language learning will be more fun. Instructional media as one of the supports learning processes that can facilitate educators in delivering and teaching material or lessons to students. Another function obtained from the use of instructional media is to increase the enthusiasm and interest of students in learning. However, not all types of media can be applied in all language skills, so it requires the accuracy of an educator in choosing media that is suitable and supports the lesson 
An Interesting learning Process can be interpreted as learning that has the element of "tickling" for students to follow. Thus students have the motivation to continue to follow learning. Fun learning means learning that matches the atmosphere that occurs in students. ${ }^{1}$ Furthermore Ibrahim Nashir conveyed in the Muqaddimati Fi atTarbiyah about the understanding of learning media as follows, namely:

$$
\text { الوسائل التربوية هي كل مايستخدم من وسـائل حسية بغية ادراك المعاني بدقة وسرعة }
$$

"Learning media is everything that is presented by concrete media in order to understand meaning accurately and quickly"2

Learning media has several Functions in the teaching and learning process that can clarify roles and information so that it can facilitate the teaching and learning process, direct students' attention so that they can increase their learning motivation, overcome sensory limitations, space and time ${ }^{3}$.

Learning media has some various types, including audio, visual, audio-visual, computer and other. However, in this paper the author specializes in visual media. In the use of visual media there are various kinds of basic principles that need to be considered in order to make it well. This is the basis of a media selection, so the role of the media as a tool to facilitate the lessons being delivered can be addressed. ${ }^{4}$ Therefore, it is necessary to discuss more deeply about the principles of visual media in learning Arabic Language and its application in the learning.

There are many conversational training techniques and models that have been developed by language teachers. Every approach or method of course puts pressure on a particular technique or model. The audio-lingual method, for example, emphasizes the need for learners to memorize the dialog model before entering into free dialogue. While the communicative method emphasizes the understanding of the dialogue model,

\footnotetext{
${ }^{1}$ M. Khalilullah, 'Strategi Pembelajaran Bahasa Arab Aktif (Kemahiran Istima' Dan Takallum)', Jurnal Sosial BUdaya, 8.02 (2011), 219-35.

${ }^{2}$ Siti Jubaidah, 'Efektivitas Pembelajaran Bahasa Arab Maharatul Kalam Dengan Media Komik Di Madrasah Aliyah Nasruddin Dampit', Jurnal Review Pendidikan Islam, 01.02 (2014) <http://jurnal.uinsu.ac.id/index.php/ihya/article/view/1529/0>.

${ }^{3}$ Husniyatus Salamah Zainiyah, Pengembangan Media Pembelajaran Berbasis ICT (Konsep Dan Aplikasi Pada Pembelajaran Pendidikan Agama Islam), ed. by Rudi Al-Hana, printed in (Jakarta: Kencana Prenada Media Group, 2017)

<https://books.google.co.id/books?id=yBVNDwAAQBAJ\&printsec=frontcover\&dq=media+pembelajaran \&hl=en\&sa=X\&ved=0ahUKEwiyy_mmpcfiAhVjmK0KHQVICEcQ6AEIXDAH\#v=onepage\&q=media pembelajaran $\& \mathrm{f}=$ false $>$.

${ }^{4}$ Nana Sudjana, Media Pengajaran (Bandung: Sinar Baru Algesindo, 2010).
} 
including the function of each phrase and its context or situation, then directly enters the real communication exercise. ${ }^{5}$

Along with the development of science, especially linguistics and methods of language teaching, learning Arabic is increasingly challenging. In Indonesia, teaching Arabic has its own challenges and problems, this is explained by Syamsuddin Asyrophy that there are three problems in teaching Arabic in Indonesia namely linguistics, methodology, and sociology. ${ }^{6}$

From three questions submitted by Syamsuddin, in the author's opinion that the teaching and learning process should be more fun, in that case teacher needs a learning media method - to deliver teaching materials to the students. According to some experts, the media has several definitions as follows:

1. Media is one of the technologies used by media users to convey messages

2. Media (as a physical form) that will convey messages, content, or material such as slides, photos, books and others

3. Media is a tool of communication in printed and audio-visual forms along with its hardware.

Media consists of two elements, namely: equipment / hardware and messages / software . Intructional media or media of learning requires equipment (hardware) to deliver content / software . So, what is called software is teaching material that will be delivered to students. However, not all media can be called as instructional media. Media that contains only teaching materials is called instructional media. For example, books that do not contain messages / teaching materials cannot be called as instructional media.

Media seen from its nature is devided into three, namely : auditive media, visual media, and audiovisual media. In this paper, the author will explain about visual media only. Visual media that can only be seen and there is no sound element. ${ }^{7}$ In the process of learning Arabic, there are various media that can be used, such as computers, record results in Compact Disk (CD), media images, and so on. Each media used has its own characteristics , and it can affect students' learning activities in Arabic. ${ }^{8}$

\footnotetext{
${ }^{5}$ Rahmaini, 'Strategi Pembelajaran Maharah Kalam Bagi Non Arab', Ihya Al Arabiyah, 1.2 (2015), $227-33$.

${ }^{6}$ Samsudin Asrofi, Metodologi Pengajaran Bahasa Arab (Yogyakarta: Ombak, 2016).

${ }^{7}$ Burhanudin et. al, Modul Media (Jakarta: Departemen Pendidikan Nasional, 2009).

8- Sukamto, - Elfizar, and - Asriyani, 'Media Pembelajaran Bahasa Arab Untuk Siswa Madrasah Ibtidaiyah', Jurnal Edukasi Dan Penelitian Informatika (JEPIN), 3.2 (2017), 104-10.
} 
The reasons underlying this paper are the absence of special studies related to the sorting of visual media that can be used in kalam learning. This is because not all visual media can be used in kalam learning. Therefore, the author tries to examine more deeply related to visual media that can be used in kalam learning

\section{Research Method}

This research is a library research by looking for various literature related to Instructional media, the methodology of teaching Arabic, and maharah alKalam(speaking skills). The research method used is descriptive analysis method. The first thing to do is to describe or provide an initial description of the problems to be discussed. Then the second one analyzes various data obtained from various literature related to this discussion

\section{Finding and Discussion}

Arabic as a language that has a high value of civilization, has its own charm and able to captivate the language observers' attention to be studied. In its own development, Arabic has become one of the international language that allows us to use, practice and even learn Arabic as a second language after their mother tongue.

Arabic has become a language that is widely studied and in demanded by almost all of people in the world, this is because Arabic is the language of Moslems Who significantly increased every year in each country. Then, there are more software, TV broadcasts and online learning in Arabic. This affects the absorption of other languages on Arabic. During the Middle century, Arabic became the main tool of culture, science, and social which caused a lot of absorbing European vocabulary from Arabic. ${ }^{9}$

In the process of learning Arabic for 'ajami (foreign speakers) or ghair natiq requires an alignment and contextualization of Arabic (as a second language) into the mother tongue. ${ }^{10}$ The process of contextualizing Arabic is one way to make students easier in understanding the meaning that suits their language right. This etymological change can be experienced by every language, including Arabic because of life progress of language users in every period.

${ }^{9}$ Rahmat Iswanto, 'Pembelajaran Bahasa Arab Dengan Pemanfaatan Teknologi', ARABIYATUNA : Jurnal Bahasa Arab, 1.2 (2017), 139-52.

${ }^{10}$ Abdul Wahab Rosyidi, Media Pembelajaran Bahasa Arab (Malang: UIN Maliki Press, 2012). 
An educator or teacher in teaching foreign languages should have a method or various ways that can make students more interesting in learning. One way that students are interested in is the learning process that uses learning media or instructional media. Teaching media is corresponded to the situation and conditions of students.

In this case, according to Syamsudin Asyrofi in Edi Komara, explains the problems in teaching Arabic, namely linguistic problems, methodology, and sociology ${ }^{11}$. The use of the right method can make the students easier to receive material and have a positive impact on students' learning outcomes. In addition to learning outcomes, the accuracy of the method can affect students' interests and motivations.

Skills that must be mastered by foreign speakers in language - including Arabic - include speaking skill (maharatul kalam), reading skills (maharatul qira'ah),listening skills (maharatul istima'), and writing skills (maharatul kitabah). ${ }^{12}$ So that the use of language as a communication tool makes language speakers understand the text and context of the language. Speaking skill (maharatul kalam) is a person's ability to pronounce articulation of Arabic sounds (ashwath 'arabiyyah) or words with linguistic rules (qawa'id nahwiyyah wa sharfiyyah) to convey ideas and feelings. ${ }^{13}$

Every language skill has a level of ability that includes performative,functional, informational,and epistemic. ${ }^{14}$ At the performative level, people are able to read (fahm maqru '), write (kafa'ah kitabah), listen (fahm masmu'), and speak with symbols (alkalam bi ramuz al-shauti) used. There is also at the functional level, people are able to use Arabic to fulfill their daily needs, such as reading newspapers, manuals or instructions. At the informational level, people are able to access knowledge with language skills. Whereas at the epistemic level, people are able to express knowledge into the target language.

In nature, humans are social creatures, the most important attitude in social is communicating. With communication, there is a process of exchanging experiences, expressing and accepting ideas or feelings, giving each other expressions and approval of

\footnotetext{
${ }^{11}$ Moh Edi Komara, 'Penerapan Metode Outbound Fun Game Dalam Pembelajaran Bahasa Arab', 9.2.

${ }^{12}$ Dhiauddin, 'هيشآب ةيفلسلا ةيملاسالإ تيوازلا يف ةءارقلا قراهم ميلعت', Jurnal Imla, 2.1 (2018), 93-102.

${ }^{13}$ Siti Jubaidah, 'Efektivitas Pembelajaran Bahasa Arab Maharatul Kalam Dengan Media Komik Di Madrasah Aliyah Nasruddin Dampit', Review Pendidikan Islam, 1.2 (2014), 247.

${ }^{14}$ Achmad Muhlis, 'Pengembangan Pembelajaran Maharah Al Kalam Berbasis Media Bithaqah Jaybiyah Di MTs Negeri Sumber Bungur Pamekasan', Okara, 2.9 (2014), 103-32.
} 
beliefs. So from here, speaking skill (which include the ability to master articulation) are very important things in human life. ${ }^{15}$

Maharah al-Kalam according to Ahmad Fuad in N. Syamaun, is the ability to express sounds of articulation or words to express thoughts in the form of ideas, opinions, desires, or feelings to the other person. In addition, the essence of maharah alkalam is the skill of using the most complicated language. ${ }^{16}$

This speaking skill requires the involvement of thoughts and feelings as well as listening skill so that the conversation can take place smoothly. ${ }^{17}$

Kalam in terminology comes from Arabic (al-kalam) which has meaning 'words or saying'. In epistemology, kalam is the pronunciation of the sounds of Arabic properly and correctly according to the sounds rules in linguistics. Whereas maharah alkalam is talking continuously without stopping, without repeating the same vocabulary. ${ }^{18}$

In this era, the 4.0 industrial revolution era, requires teachers to be more creative and innovative in attracting the attention of their students in the learning process. One habit that is owned by the current generation is that there is an interest in visual things. It can have an impact and differences in the learning outcomes of Arabic Language students who use audio-visual media with those who do not use audio-visual media. As explained by Rukman and Harnika, the use of audio visual media in the process of learning Arabic can improve listening skill in Arabic, especially grade VIII students at MTs As-iAdiyah Pengkendekan Luwu Utara. ${ }^{19}$

Instructional media has a very important role in the learning process, especially learning Arabic. Among its roles is as a media or tool that can help the teachers in the process of explaining and delivering material to students. On the one hand, the teacher / educator is the main model of learning that is seen and heard directly by students. however on the other hand, sometimes the media has a role in the learning process, and

\footnotetext{
${ }^{15}$ Rahmaini.

${ }^{16}$ Nurmasyithah Syamaun, 'Pembelajaran Maharah Al-Kalam Untuk Meningkatan Keterampilan Berbicara Mahasiswa Program Studi Pendidikan Bahasa Arab Fakultas Tarbiyah Dan Keguruan UIN Ar-Raniry Banda Aceh', Jurnal Lisanuna, $4.2 \quad$ (2015), $343-59 \quad<$ https://jurnal.arraniry.ac.id/index.php/lisanuna/article/view/852>.

${ }^{17}$ Rahmaini.

${ }^{18}$ Kuswoyo, 'Konsep Dasar Pembelajaran Maharah Al-Kalam', An-Nuha, 4.1-10 (2017), 1-10.

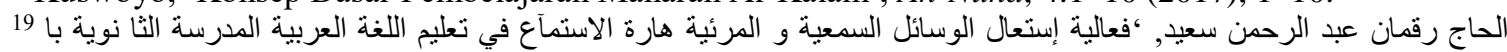
نجكينديكان بافصلاالثامن في لووو الثِثِمالية.', AL IBRAH: Journal of Arabic Language Education, 1.1 (2018), 59-72.
} 
the teacher / educator as a supplement adds an explanation that has not been conveyed clearly. ${ }^{20}$

Based on the explanation above, visual methods can be used in learning Arabic because of the need to adjust to the interests of students who are now the majority of the millennial generation. An educator or teacher can choose various types of visuals in delivering the subject matter. The selection of this type of visual is not only considered for the material explanation but the learning assignments that will be assigned must be adapted to the media.

Particularly, visual media has a function to attract attention, clarify presentation of ideas, illustrate or decorate facts that might be quickly forgotten if not graphed. Then, students are also more interested in visual media, especially those that have varied choices, simple, and realism. In addition, by using visual media, there will be a climate or learning atmosphere that is fun and more interesting to learn about. ${ }^{21}$

According to Sharon, visual discussion can be divided into six parts, namely realistic, analogical, organizational, relational, transformational, and interpretative. ${ }^{22}$

\section{a. Realistic}

This realistic becomes a part of the visual method described by Sharon because visual reality tries to visualize or display objects in real from the object being studied. Example of visualizing a picture of a rabbit (arnab) during a reading (muthala'ah) activity.

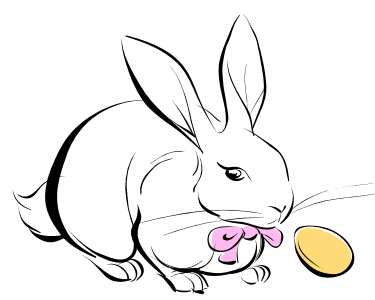

Picture 1. Visualization of rabbit

\section{b. Analogical}

In this analogical type, it is expected that messages, concepts, or topics are

\footnotetext{
${ }^{20}$ Siti Mahmudah, 'Media Pembelajaran Bahasa Arab', An Nabighoh Jurnal Pendidikan Dan Pembelajaran Bahasa Arab, 20.01 (2018), 129-38.

${ }^{21}$ Baiq Tuhfatul Unsi, 'Media Gambar Dalam Pembelajaran Kosakata Bahasa Arab', Tafaqquh, 2.1 (2014), 26-44.

${ }^{22}$ Sharon Smaldino, Instruksional Technology \& Media for Learning (Jakarta: Kencana Prenada Media Group, 2011).
} 
conveyed well to students by showing or visualizing something else that is similar or similar to the message.

c. Organizational

Visual in this part will display system of structured diagrams with one relating to each other as a unitary element such as classification diagrams, timelines, flowcharts and maps. For example in Arabic learning the distribution of Verb (Fiil) in shorf . Organizational diagrams will make students easier to memorize the distribution of fiil

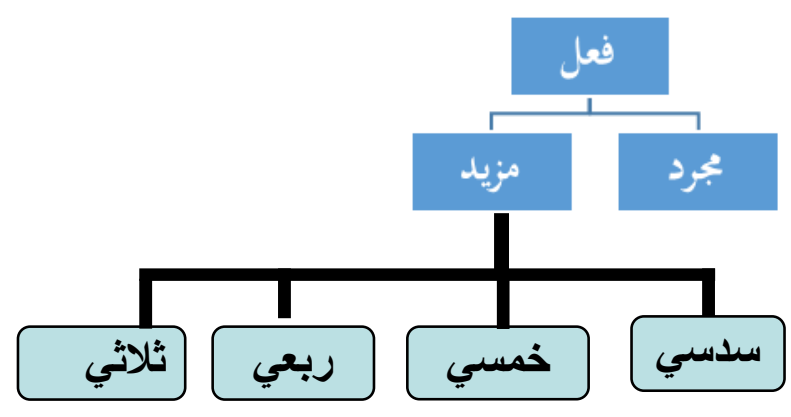

Picture 2. Organizational Fi'il

\section{d. Relational}

Visual relational is a visual that displays different relationships with organizational (quantitative). Like the form of bar charts, graphs and lines

\section{e. Transformational}

In this part, transformational visual methods will visualize a change based on the context of time and place. Like the process of change or the cycle of animated images of the water cycle or a procedure for how to tie shoelaces or make steel. In learning Arabic, a teacher can make transformational diagrams when explaining the process of descending the Qur'an.

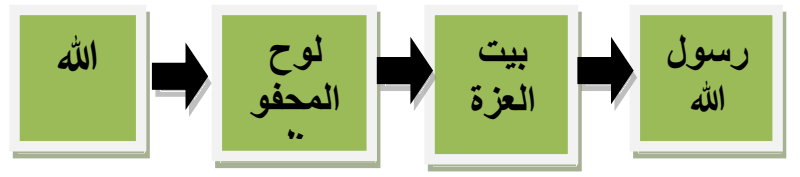

Picture3. Transformational

\section{f. Interpretative}

This interpretive section becomes a medium that will describe theoretical and abstract relations. 


\section{Principles of Using Visual Media}

The use of visual-shaped learning media has several principles that can make the visual media more effective, namely: 1) visual simplification with charts, diagrams, or lines; 2) using visual methods as a means of suppressing information; 3) the use of graphics to conclude the entire material; 4) do visual repetition by involving students; 5) The use of images to distinguish one concept from another; 6) visuals must be balanced; 7) all visuals must be clear and precise; 8) using colors that are easy to remember; 9) images using captions.

\section{Visual Design Guide}

In making visuals, a teacher must know about basic guidelines for how to design good visuals. It aims to be visually designed to attract students' attention and facilitate understanding. The elements must be in the visual media, including arrangement, alignment, form, one-third rule, closeness, direction, direction, contrast of figure or background, consistency, balance, color, readability, and attractiveness.

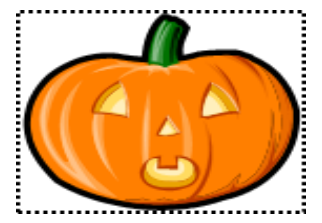

Picture 4. Leveling

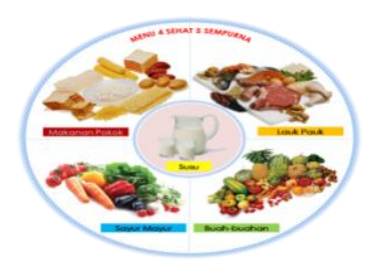

Picture 5. Shape 


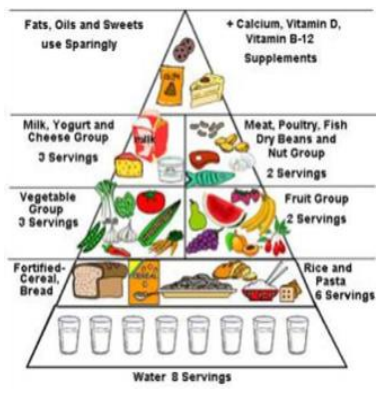

Picture 6. Triangle

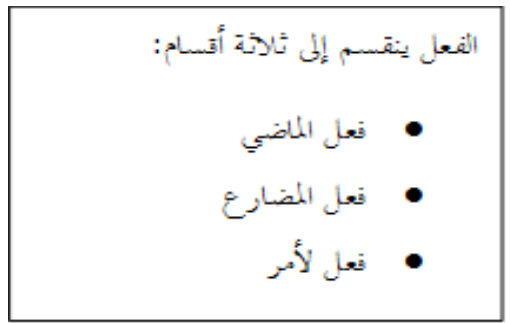

Picture 7. Closeness

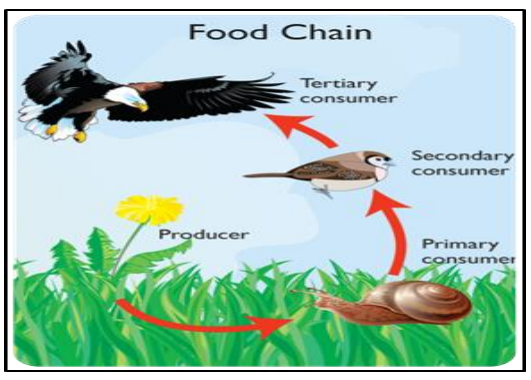

Picture 8. Direction

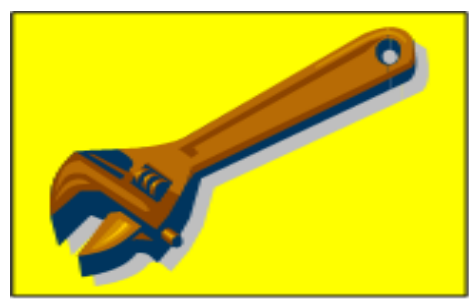

Picture 9. Contrast Background
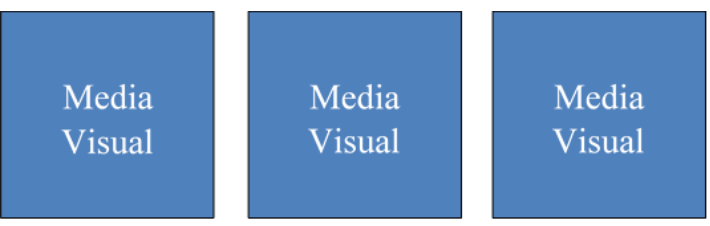

Picture 10. consistency 


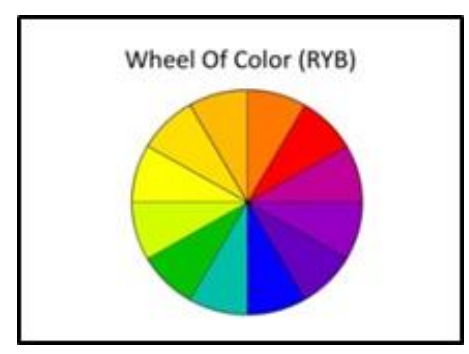

Picture 11. Colors

In visual display, a teacher does not only display images, but includes textual information. The text on a material that will be displayed also has its own elements, including :

a. Style

For the teaching and learning purposes or the information being transferred the selected writing should be consistent, plain text style (no decoration), and simple writing. For example, Sans Serif writing style like Arial and Times New Roman..

\begin{tabular}{|l|}
\hline M E D I A \\
\hline V ISUAL \\
\hline LANGUAGE \\
\hline $\begin{array}{l}\text { Visual media is a media that only be seen and there is no } \\
\text { sound element in it. }\end{array}$ \\
\hline $\begin{array}{l}\text { Visual media is a media that only be seen and there is no } \\
\text { sound element in it. }\end{array}$ \\
Visual media is a media that only be seen and there is no \\
sound element in it.
\end{tabular}

b.Size

Determining the size of a text to be visualized must adjust to the conditions of the students. For example, so that it can be read by all students either sitting in the front or back row, at least $1 \frac{1}{2}$ inches of text size.

c. Space

The space between each letter should use optical spacing, which mostly eyes can see, Whereas vertical spaces between each line, may not be too close together and may not be too tenuous. 
d. Color

Determining the color that will be used in the instructional media should be contrast in order can be seen clearly by students.

Example:

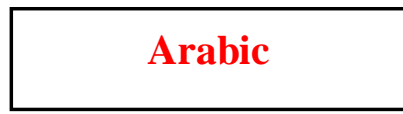

e. Use of uppercase letters

Large-sized letters are used so that students can easily read the material submitted.

\section{Drawing Pictures}

If students are planning a series of visuals, for example some OHP transparencies that are interrelated, a set of powerpoint slides or a series of computer screens, then storyboarding is a useful method for planning.

1. Techniques for making letters

Various letter making techniques can be used for visuals. The simplest thing is to make letters with markers and feather-tipped pens. The letters that have been cut into pieces that are already available at the office stationery store, are easier to use and most can be directly affixed. Drawing, sketching and making cartoons. Sketching or drawing is very helpful to facilitate conveying messages to students.

2. Clip art

Clip art are visual images that are prepared (digital images), which can be inserted in various digital documents and presentations

3. Designing a visual media with a computer

With presentation graphics software, such as Microsoft Powerpoint or Apple Keynote can create graphics that are suitable for professional presentations. The types of graphic software include presentation programs, drawing and coloring programs, diagramming programs, photo enhancement programs, and desktop publishing programs.

4. Making graphics presentation

The guide for making presentation graphics, as follows: determine the font, size and color; plain and brightly colored background; the title is in the middle; use short 
communication; template to create a consistent visual format; slides to create a consistent text format; reduce "bells or whistles", sounds that can disrupt students' concentration; use the appropriate image; use consistent transitions (alternating slides); using a building (the entry of text into a slide) is simple; use animation that supports teaching messages rather than adding dramatic effects to the presentation; reduce the use of sound; use footnotes to identify slides; make transparent projector overhead (OHP)

Things that must be considered include:

a. Ordinary pens with continuous ink in water generally do not stick to the acetate sheet, the ink tends to clot and then evaporates

b. Use a pen marked "OHP projector pen" created to project colors

c. Permanent ink can be removed using special plastic removal or with an eraser containing an alcoholic solution.

Apart from making pictures, there are ways to capture images, that is:

\section{a.Photography}

Photography For the purpose of teaching, the subject must be interesting and imaginative. The elements of the picture should be relevant to the purpose of teaching and should be made or framed in the picture correctly. Printing digital images is very easy quickly with color printers or photo printers.

\section{b.Scanner}

The scanner works with computers to convert paper-based visual images, such as images or student photos, into digital computer image files.

\section{Implementation of Visual Media in Maharatul Kalam}

In teaching speaking skill, students need to pay attention to their abilities. Teachers need to know the level of ability they have, what they will do with that, the teacher can determine what material will be given to students. Speaking ability holds fast that language is a communication tool so students must use language actively. In linguistic terms, oral messages delivered by speaking are the use of words chosen in accordance with the intentions that need to be expressed. The words are arranged in a certain arrangement according to the rules of grammar and are recited according to the proper pronunciation rules. All aspects of language are part of speaking activities as a form of spoken language. The speaker must be able to strive so that the message 
delivered can be understood by the listener as intended by the speaker.

The visual media that can be used in kalam learning include: posters, flannel boards, images, bulletin boards. From the six media, the author will detail how to use the media above in the lesson learning, as follows:

1.Poster

The poster is a clear, striking and interesting visual presentation with the intention of attracting the attention of passersby. Posters can influence behavior, attitudes and values of society to change or do something. This poster media can be used for the benefit of learning, which is intentionally installed inside and outside the classroom. In learning Arabic especially kalam, this poster media can be used as one of the media in delivering the material of the kalam. In its use, the teacher first chooses the topic to be presented, then searches / makes a poster related to the topic to be presented, in addition to the poster used this must be relevant to the objectives and material presented.

\section{Flanel Board}

Flannel boards are flannel-coated boards to present images or words that are easily pasted and easily removed. This tool is made of black or blue flannel cloth mounted on a wall or hung between two pieces of wood in the upper and lower chart. The images are mounted on a flannel cloth, the back of the image is glued to make it easy to glue and remove. Through this tool, various images such as clothing, animals, fruits, family members and others can be clearly shown. Flannel board is an effective graphic media for presenting certain messages to certain targets as well as flannel boards including one of two-dimensional visual learning media.

The advantages of using flannel boards are easily attached images, time and energy efficiency, attracting students' attention, making it easier for teachers to explain the material.

\section{Bulletin Board}

Bulletin board is an ordinary board coated with flannel. Pictures and writings can be directly attached using glue or other sticking tools. Bulletin boards are widely used in universities as learning media that can improve kalam skills. This media is used to carry out language learning activities, so students who do not participate in the bulletin will be left behind. The bulletin is managed well and professionally, so that it 
can attract and help in learning Arabic (kalam). The use of bulletin boards can be done by attaching clipping from Arabic-language newspapers or Arabic-language magazines, taking into account the following points.

a. Clipping should be arranged and neatly designed

b. Use colored writing

c. Students are encouraged to read it to find out what happened

d. Ornament displays must be replaced to make them look fresh and up to date clipping

4. Picture

Media images can also be called as persistence images. Picture media is visual media produced through the photographic process, this type of media is a photo. The word image includes all kinds of paintings and illustrations used in the presentation of the language learning process. Pictures that are installed in front of the class should be large and clear enough to be easily seen by students. The use of images needs to get attention from the teacher and the first step taken is preparation. The presence of images does not guarantee the student's attention. Therefore, the teacher should invite students to be active and explain to students about what needs attention.

In learning Arabic this media image can be used as a topic of conversation. Usually in the learning process, the teacher conveys the material on a topic using the story method and then asks questions and answers. Sometimes students are less interested if they just listen to the story, but with this picture the participants will be more interested in listening to the story and holding answers. This image media is combined with the story method and question and answer, so that it will be more effective to be applied in an Arabic language learning.

5. Clock

According to Abd Wahab Rosyidi, clock is the most successful media in learning Arabic. This media is made and obtained by a teacher, usually consisting of $1-12$, long needles, medium needles and short needles. However, before using this clock media, it must be ensured that participants are familiar with the count of one to sixty. The next step is for the teacher to turn the clock as usual, after making sure the clock shows a certain number, the teacher asks a variety of questions. 


\section{Conclusion}

From the discussion above it can be seen that in using visual-based learning media / instructional media there are various kinds of rules. Existing arrangements are made with the aim of making effective use of visual media in learning. The use of good media will influence the arrival or failure of messages (learning material) to students. The visual media intended is media that can only be seen, without any sound element. The types of visuals are realistic, analogical, organizational, relational, transformational and interpretive. In addition, there are principles in the use of visual media including the recommended simplicity, clarity, readability and others. The visual design guide has two elements, namely visual elements and text elements. Visual elements include five things, namely setting, balance, color, readability and attractiveness. Furthermore, the text elements include style, size, space, color and use of uppercase letters. What needs to be considered when desire to use images as a form of visual media is planning tools, letter making techniques, drawing, sketching, making cartoons, clip art, designing a visual with a computer, making presentation graphics, making an overhead projector (OHP). In addition, in capturing images there are also two ways, namely photography and scanner. In its implementation, visual media can be implemented in learning Arabic, one of which is kalam learning. Visual media that can be used include images, posters, flannel boards, bulletin boards and clocks. This type of visual media is one of the media that can be used in learning Arabic, so that learning Arabic can be successful.

\section{References}

Burhanudin et. al, Modul Media (Jakarta: Departemen Pendidikan Nasional, 2009)

Dhiauddin, 'هيشآب ةيفلسلا ةيملاسالإ ةيوازلا يف ةءارقلا ةراهم ميلعت', Jurnal Imla, 2 (2018), 93-102

Husniyatus Salamah Zainiyah, Pengembangan Media Pembelajaran Berbasis ICT (Konsep Dan Aplikasi Pada Pembelajaran Pendidikan Agama Islam), ed. by Rudi Al-Hana, Cetakan ke (Jakarta: Kencana Prenada Media Group, 2017) <https://books.google.co.id/books?id=yBVNDwAAQBAJ\&printsec=frontcover\&dq =media+pembelajaran\&hl=en\&sa=X\&ved=0ahUKEwiyy_mmpcfiAhVjmK0KHQ VICEcQ6AEIXDAH\#v=onepage $\& \mathrm{q}=$ media pembelajaran $\& \mathrm{f}=$ false $>$

Iswanto, Rahmat, 'Pembelajaran Bahasa Arab Dengan Pemanfaatan Teknologi', 
ARABIYATUNA : Jurnal Bahasa Arab, 1 (2017), 139-52

Jubaidah, Siti, 'Efektivitas Pembelajaran Bahasa Arab Maharah al-KalamDengan Media Komik Di Madrasah Aliyah Nasruddin Dampit', Jurnal Review Pendidikan Islam, 01 (2014) <http://jurnal.uinsu.ac.id/index.php/ihya/article/view/1529/0>

—, 'Efektivitas Pembelajaran Bahasa Arab Maharah al-KalamDengan Media Komik Di Madrasah Aliyah Nasruddin Dampit', Review Pendidikan Islam, 1 (2014), 247

Khalilullah, M., 'Strategi Pembelajaran Bahasa Arab Aktif (Kemahiran Istima' Dan Takallum)', Jurnal Sosial BUdaya, 8 (2011), 219-35

Komara, Moh Edi, 'Penerapan Metode Outbound Fun Game Dalam Pembelajaran Bahasa Arab', 9

Kuswoyo, 'Konsep Dasar Pembelajaran Maharah Al-Kalam', An-Nuha, 4 (2017), 1-10

Mahmudah, Siti, 'Media Pembelajaran Bahasa Arab', An Nabighoh Jurnal Pendidikan Dan Pembelajaran Bahasa Arab, 20 (2018), 129-38

Muhlis, Achmad, 'Pengembangan Pembelajaran Maharah Al Kalam Berbasis Media Bithaqah Jaybiyah Di MTs Negeri Sumber Bungur Pamekasan', Okara, 2 (2014), 103-32

Rahmaini, 'Strategi Pembelajaran Maharah Kalam Bagi Non Arab', Ihya Al Arabiyah, 1 (2015), 227-33

Rosyidi, Abdul Wahab, Media Pembelajaran Bahasa Arab (Malang: UIN Maliki Press, 2012)

Samsudin Asrofi, Metodologi Pengajaran Bahasa Arab (Yogyakarta: Ombak, 2016)

Sharon Smaldino, Instruksional Technology \& Media for Learning (Jakarta: Kencana Prenada Media Group, 2011)

Sudjana, Nana, Media Pengajaran (Bandung: Sinar Baru Algesindo, 2010)

Sukamto, -, - Elfizar, and - Asriyani, 'Media Pembelajaran Bahasa Arab Untuk Siswa

Madrasah Ibtidaiyah', Jurnal Edukasi Dan Penelitian Informatika (JEPIN), 3 (2017), 104-10

Syamaun, Nurmasyithah, 'Pembelajaran Maharah Al-Kalam Untuk Meningkatan Keterampilan Berbicara Mahasiswa Program Studi Pendidikan Bahasa Arab Fakultas Tarbiyah Dan Keguruan UIN Ar-Raniry Banda Aceh', Jurnal Lisanuna, 4 (2015), 343-59 <https://jurnal.ar-raniry.ac.id/index.php/lisanuna/article/view/852> Unsi, Baiq Tuhfatul, 'Media Gambar Dalam Pembelajaran Kosakata Bahasa Arab', 
Tafaqquh, 2 (2014), 26-44

سعيد, الحاج رقمان عبد الرحمن, 'فعالية إستعال الوسائل السمعية و المرئية هارة الاستمآع في تعليم اللغة العربية المدرسة الثا نوية با نجكينديكان بافصلاالثامن في لووو الشِّمالية IBRAH: Journal of Arabic Language Education, 1 (2018), 59-72 